\title{
UTOPIA, DYSTOPIA AND UCHRONIA IN CHRONICLES
}

\author{
ROLAND BOER \\ UNIVERSITY OF NEWCASTLE
}

Steven Schweitzer`s Reading Utopia in Chronicles (2007) breathes the excitement of a new insight into that quiet corner of biblical scholarship that is Chronicles $\square$ study. Along with work on Chronicles by Christine Mitchell, Julie Kelsos new book, O Mother, Where Art Thou? (Equinox 2008), and the edited collection by Ehud Ben Zvi called Utopia and Dystopia in the Prophetic Literature (2006), it looks as though Chronicles $₫$ scholarship is at the beginning of a shakeup. All of them share the assumption that for all the gains of historical critical study, its agenda it too limited and it leaves too many questions begging about this fascinating literature.

The angle Schweitzer pursues comes from utopian literary criticism, a thriving area that explores the nature, history and possibilities of utopian literature that includes Thomas Mores Utopia (1516) but then also pushes further back. The discussion by Schweitzer of utopian literature, its theory and criticism is as good an introduction of the major issues as you are likely to find. I suspect that a good number of people will end up referring to it when they need a concise, lucid statement of that theory. We find the key critics who have dealt with utopia: the important figure of Ernst Bloch and his utopian project, Darko Suvins work on utopia and science fiction, the innovations of Louis Marin, Fredric Jamesons lifelong interest in utopian literature and what he calls the utopian project, as well as Lyman Tower Sargent on whom Schweitzer relies quite heavily. There is also a very useful excursus on Thomas More who wrote the first work actually called Utopia back in 1516. Here we find the traveller, Raphael Hythloday (meaning speaker of nonsense, one of the many wordplays in the book), describing to a certain Peter Giles the social, political, religious and economic structure of an island he claims to have visited called Utopia, which means both (in Greek) ou-topos, no place, and eu-topos, good place. In Schweitzers discussion we find the crucial point that utopia is not an imaginary world of dreamers. Rather, as with Thomas More's work, utopia offers as much a critique of existing society as ways to improve it. Or, as Schweitzer puts it, utopia is concerned with a better alternative reality. On this light, any political program

This work is licensed under a Creative Commons Attribution 2.5 Generic License. To view a copy of this license, visit http://creativecommons.org/licenses/by/2.5/ 
worth its salt is utopian. Indeed, utopian literature might be regarded as a form of public policy. Schweitzer also makes the important point that utopia is not necessarily, as it is often believed, a future reality in an inaccessible place such as an island or another planet (common on the science fiction version). By contrast, it may well be contemporary with the author and the society being criticised $\square$ as is the case with Thomas Mores book.

Now Schweitzer makes much of the idea that utopia $\square$ really means a ظetter alternative reality $\square$ (a phrase you will find more than once in the book). This is a workable proposal, especially since it negates the popular pie-in-the-sky version of utopia. However, it seems to me that a better insight into his whole argument is that the Chronicler (we really need to come up with a better name for this unknown author or group of authors) was an innovator and not a legislator (p. 136). This is a crucial move, for unlike the majority of commentators who seek out historical detail, or who see the Chronicler as one who wanted to lock in certain practices of his (or their) time, Schweitzer argues that the Chronicler is far more imaginative than that.

All of this Schweitzer brings to bear on Chronicles. Here he argues that the substantial insights of utopian literature and its theory are able to make sense of many of the problems in Chronicles before which historical criticism is at a loss. So the text turns out to be a series of utopian explorations based on three key features. First, there are the rich genealogies in the first chapters of 1 Chronicles. These genealogies play with time, stretching it out at some points and collapsing it in others. They shift from one type of genealogy to another and they connect characters in unexpected ways. The issue of time is crucial and I will return to it in a moment.

Second, there is a detailed retelling of political history, especially in relation to the narrative in Samuel $\square$ Kings. More specifically, the political history of the kings of Judah presents a very different picture from that other account in 1 and 2 Kings. Chronicles tells a more hopeful story than the fatalistic inevitability of the books of Kings. It is an old adage, but one of the ways of opening up a different understanding of the present and thereby new possibilities for the future is to retell the story of how we got here. In this respect historiography $\square$ which is really a way of telling a story $\square$ is an important feature of a utopian program. I found this section quite persuasive, especially in the way Schweitzer traces the way dystopia and utopia play off against one another. Schweitzer uses the scale of utopia-dystopia to assess the representations of the kings. So what we find is that David and Solomon are utopian kings, while Jehoram, Ahaziah and Athaliah all come through as dystopian rulers. Even more, within the reigns of some of kings there is a shift: Jehoshaphat, for example, moves from utopia to dystopia while Hezekiah shifts from a dystopian beginning to a utopian close. 
The final utopian feature of Chronicles is for Schweitzer the re-organisation of the temple and its worship, or, in short, the cult. In many respects, it seems to me that this is the key to Chronicles. In presenting a world in which ritual and its organisation are carefully ordered, Chronicles seeks to present a better world than the present one. At this point I must ask whose utopia this is, although I will hold off answering that question for now.

Inevitably, there are points where more needs to be done. As Robert Culley once said to me, you never finish a book; you just stop working on it for now. To begin with, I was not overly impressed with the discussion of Marxism, especially the argument that Marxism has been opposed to utopias and their plans. At one level, Schweitzer has a point, for one influential group that Marx and Engels battled in the 19 $9^{\text {th }}$ century were the utopian socialists who often drew their inspiration from the Bible and sought to recreate the legendary communist living of the early church. This line of socialism came through from medieval communal movements, but above all the French socialists Fourier and Ste. Simon, as well as their followers in the rest of Europe. Marx and Engels were often scathing in their treatment of these crude and woollyheaded comrades. Since then there have been a good number of Marxists opposed to any utopian program. However, there are even more who feel that Marx and Engels were too hard on the utopian socialists (in the name of scientific socialism) and that they did have something valuable to say. So we now find that utopia is often used as a code for socialism itself. Names such as Darko Suvin, Elisa Cevasco, Peter Fitting, Andrew Milner, China Miéville, Karl Kautsky, William Morris and of course Fredric Jameson suggest that socialism and utopia have a lot in common, for all of these are Marxists vitally interested in utopia. In fact, I would suggest that the development of the idea that utopia means pie in the sky $\square$ may in fact be read as a response to socialism $\llbracket$ close connection with utopian social movements: that way you can dismiss socialism as the stuff of hopeless dreamers.

Further, it seems to me that Schweitzer`s study begs the category of uchronia. If utopia is the no place $\square$ that is also the good place, then uchronia is both no time $\square$ and good time $\square$ Uchronia, then, is an alternative and better way of dealing with time, and the most common way that happens is through rewriting history. Without naming it uchronia and without discussing the category, Schweitzer argues in a uchronian way at major points in his book: in the genealogies we find time stretched and collapsed; in the alternative history of the kings of Judah there is a distinct effort to retell the story in a better light. There are hints that Schweitzer is aware of this, such as the mention of an idealized portrayal set in Israel $\sqrt{\text { s past }} \square$ (p. 30). But the better category is in fact uchronia. As I pointed out earlier, rewriting a history actually opens up the chance for a very different and better present. 
Another element worth further exploration is the suggestion by Louis Marin in his Utopiques that utopias are unstable things; you cant quite lay your hand on one, for as soon as you do, it slips away. Marin shows how even Thomas Mores Utopia was full of formal contradictions and problems. For example, Mores effort to describe the layout of towns on the island of Utopia doesn $t$ work when you try to draw a map according to his guidelines. There are anomalies and confusions in the map. Of course, More may have just been lazy, or perhaps a bad describer of such things, but Marin argues that these anomalies are the stuff of utopia. In fact, utopias begin to emerge in these narrative cracks, in the contradictions and tensions where a new possibility begins. There are some glimpses of this feature of utopia in Schweitzers book, especially when he explores how the Chronicler plays with time and space, and how the description of the temple and its organisation doesnt quite work. He suggests that what we have are shifting utopias, experiments with different types that then overlay one another, an adaptability in the effort to construct utopia.

There is a further feature of this instability and tendency to contradictions in any effort to depict utopia. And that is what may be called the tension between an open and closed utopia. David Harvey has put this rather well in his Spaces of Hope: many utopias feel the need at some point to say this is it, we ve achieved our ideal. The catch is that the moment of closure needs someone to make the decision to close things up. When that happens, you get the threat of authoritarianism. Utopia is frozen, as all too many religious communities have found through history. The other possibility is that utopia is perpetually open. As an experiment, as an exploration of different possibilities, open to failure and the need to start again, open utopias do not need to face the authoritarian threat of closure. The plural is important, for if we speak of utopia $\square$ we get the impression of one model and one program, which inevitably has to exclude others. However, with plural utopias we encourage openness. It seems to me that Chronicles hovers between these two options. There are a good many sections where closure is sought for a single utopia, but then there are others where the various experiments and options point towards a plural openness.

All the same, there are two questions that need to be asked. When speaking of utopia we always need to ask: utopia for whom? Dystopia for whom? For Schweitzer, it may well be a series of utopias for the Levites, who come out rather well in the reconstructions of the cult. But then we need to ask for whom this might well be a dystopia. A Levite utopia may not be all that positive for women, for example, or foreigners, or anyone else who is not part of the in-group. One person $s$ utopia is another $\$ dystopia. Utopian literature is full of this play between utopia and dystopia, so much so that some have suggested utopia can emerge only in the tension between them. 
Let me finish on a slightly different note. About a decade before the discussion of Steven Schweitzers book at the SBL meeting in San Diego (2007), I gave a paper at the same section on nothing less than the utopian politics of Chronicles, which eventually became part of my book Novel Histories (1997). The Chronicles, Ezra and Nehemiah group of the mid 1990s gave me that puzzled and pitying look usually reserved for aliens who speak a different language (Australia is a good distance away but we do speak a version of English). They really couldn t figure out what I was on about. I decided never to return to this quiet coterie of traditional historical critics. So it was with some surprise and enjoyment to turn up to the same section some ten years later and find that things are in ferment, not least of which was the discussion of Schweitzer S book. 